\title{
Effect of vegetable oil oxidation on the hydrogenation reaction process
}

\author{
By Faranak Kalantari, ${ }^{a}$ Manochehr Bahmaei, ${ }^{\text {b* }}$ Majid Ameri ${ }^{a}$ and Ehsan Shoaei ${ }^{a}$ \\ ${ }^{\text {a }}$ Research and Development Laboratory, Savola Behshahr Company (SBC), $8^{\text {th }}$ Fath Highway, \\ Tehran, Iran ${ }^{b}$ Islamic Azad University North Tehran Branch, Tehran, Iran \\ ( ${ }^{*}$ corresponding author: mbahmaie@ savola.com)
}

\section{RESUMEN}

\author{
Efecto de la oxidación de aceites vegetales en el \\ proceso de hidrogenación
}

La hidrogenación fue llevada cabo en un reactor discontinuo con tres aceites decoloradas y oxidadas con objeto de estudiar el efecto de la oxidación en el proceso de hidrogenación. Las especificaciones de los aceites hidrogenados tales como el punto de fusión, índice de yodo, contenido de grasa sólida y composición de ácidos grasos de los aceites oxidados fueron comparados con sus correspondientes aceites de referencia sin oxidar. El aceite de girasol decolorado y oxidado fue hidrogenado hasta alcanzar un punto de fusión $\left(34,39\right.$ and $\left.42^{\circ} \mathrm{C}\right)$ con altos índices de yodo versus su aceite de referencia con el mismo tiempo de reacción. Aceites decolorado y oxidado de soja y de canola fueron hidrogenados hasta alcanzar puntos de fusión $\left(34,39\right.$ y $\left.42^{\circ} \mathrm{C}\right)$ con altos valores de yodo, pero los tiempo de reacción fueron más largos que en sus aceites de referencia. Los resultados del contenido de grasa sólida y ácidos grasos trans de todos los aceites hidrogenados fueron menores que sus correspondientes referencias. Un valor de peróxidos sobre $0.5 \mathrm{meq} \mathrm{O}_{2} / \mathrm{kg}$ para aceites no autooxidados y sobre 5 meq $\mathrm{O}_{2} /$ kg cambiara significativamente el proceso de hidrogenación.

PALABRAS CLAVE: Aceite vegetal - Composición de ácidos grasos - Contenido de grasa sólida - Oxidación Tiempo de hidrogenación.

\section{SUMMARY}

Effect of vegetable oil oxidation on the hydrogenation reaction process

Hydrogenation has been carried out in a batch reactor with three different oxidized bleached oils in order to discover the effect of oxidation on the hydrogenation reaction process. Specifications of hydrogenated oils such as melting point, lodine value, solid fat content and fatty acid composition of the oxidized oils were compared with their un-oxidized reference oils. Oxidized bleached sunflower oil was hydrogenated to target melting points $\left(34,39\right.$ and $\left.42^{\circ} \mathrm{C}\right)$ at higher iodine values vs. its reference oil with the same reaction time. Oxidized bleached soybean and canola oils were hydrogenated to target melting points $\left(34,39\right.$ and $\left.42^{\circ} \mathrm{C}\right)$ at higher iodine values as well, but reaction times were longer than their reference oils. The resulting solid fat content and total trans fatty acids of all hydrogenated oils were less than their references. A peroxide value above $0.5 \mathrm{meq} \mathrm{O}_{2} / \mathrm{kg}$ for non auto-oxidized oils and above $5 \mathrm{meq} \mathrm{O}_{2} / \mathrm{kg}$ for auto-oxidized oils will significantly change the hydrogenation process.

KEY-WORDS: Fatty acids composition - Hydrogenation time - Oxidation - Solid Fat Content - Vegetable oil.

\section{INTRODUCTION}

Modification processes increase the usability of edible oils. These processes consist of hydrogenation, interesterification and fractionation (Gunstone et al. 1994). The changes in processing equipment and processing conditions may influence hydrogenation (Podmore 1990). Pressure, temperature, catalyst concentration and the rate of agitation are among the important factors which are effective on the behavior of hydrogenation. Also cis-trans isomerization which occurs during hydrogenation can be influenced by the nature of feed stock (Hastert 1991). Hydrogenation is impeded by a variety of catalyst poisons, and it is the aim of pretreatment to diminish them to a negligible level (Patterson 1994). Phosphatides, free fatty acids, soaps and oxidation products tend to be adsorbed on the surface of the catalyst. Oxidation products resulting from oil oxidation poison the catalysts as well.

Modern bleaching processes are conducted under vacuum $(50 \mathrm{mmHg}$ ) to minimize oil oxidation, and subsequent nitrogen blanketing is recommended (Riegel and Kent, 2003). Generally, the oil which is used for hydrogenation is chemically refined and bleached oil. The oil specifications for hydrogenation have been reported and, among them, a peroxide value lower than $0.5 \mathrm{meq} \mathrm{O}_{2} / \mathrm{kg}$ of oil has been established (Kellens 2000):

Oxidation happens when the process does not run well in the bleaching step and it is enhanced by prolonged or bad storage conditions of either crude oil or refined/bleached oil.

The peroxide value (PV) is a good indication of oxidation, but as this test is empirical, the results are not stable regarding the test conditions. Since PV measures hydroperoxides (which are transitory), the test is supported by the $p$-Anisidine value (p-AV) to give a better view of oil oxidation. If a low p-AV (less than three) is found combined with a low PV, then it indicates there is no significant loss of natural antioxidant from the oil (Podmore, 1990; Oliver and Roland Meyer, 2004; Wong, 1989). Oil oxidation is usually characterized by the Totox (Total Oxidation) value that includes the results from the peroxide and the $\mathrm{p}-\mathrm{AV}$ measurements (Patterson, 1994; Shahidi and Zhong, 2005; Shahidi and Wanasundara, 2002; Min and Hyung-Ok, 1999).

$$
\text { Totox }=A V+2(P V)
$$


Different groups have investigated the effect of different refining processes or different operating conditions on the hydrogenation reaction process (Hastert, 1991; Ariaansz and Okonek, 1998; Strecker et al. 1986; Bockisch, 1993; Hastert, 1987), but only a few groups have researched the influence of the Totox value on the hydrogenation process (Drozdowski and Zajac, 1977; DeBonte, 2004).

The aim of this work is to describe the influence of the Totox value on the vegetable oil hydrogenation process. Three different vegetable oils i.e. soybean, sunflower and canola oil were selected and subjected to hydrogenation. These oils were stored at defined temperatures, sampling was done at different intervals, and PV and $\mathrm{p}-\mathrm{AV}$ were measured simultaneously. Finally, the samples were subjected to hydrogenation. Resulting iodine value (IV), melting point (MP), solid fat content (SFC) and fatty acids compositions were measured and compared with their corresponding reference oils.

\section{MATERIALS AND METHODS}

\subsection{Materials}

The bleached vegetable oils i.e. soybean (SBO), sunflower (SFO) and canola oil (CNO) were obtained from Behshahr Ind. Company (Tehran, Iran). A commercial Nickel based catalyst 9910 was purchased from Johnson Matthey Co., citric acid from Merck (Germany) which is used for separating catalysts using filter paper of Whatman 90 (England). Analytical grade solutions and solvents for measuring peroxide, $p$-Anisidine, iodine value and fatty acid composition were purchased from Merck (Germany).

\subsection{Methods}

\section{Storage and Sampling}

The bleached vegetable oils were stored under florescent light at $35^{\circ} \mathrm{C}$ for 135 days, the PV and $\mathrm{p}-\mathrm{AV}$ of the oils were measured on a daily basis and whenever the Totox value increased significantly, sampling was done for hydrogenation.

\section{Hydrogenation of the samples, sampling, catalyst removal}

Hydrogenation was performed at $170 \pm 2{ }^{\circ} \mathrm{C}$ under 1 bar pressure in a continuously stirred slurry reactor (300ml, KMF-HAARLEM of Holland). $250 \mathrm{~g}$ oil and the nickel catalyst $(0.25 \mathrm{~g})$ were added to the reactor. During hydrogenation, Hydrogen gas was disconnected and three successive samples were selected with MPs of 34,39 and $42^{\circ} \mathrm{C}\left( \pm 0.2^{\circ} \mathrm{C}\right)$. Reaction time was recorded for each individual sample. Filter aid $(0.125 \mathrm{~g})$ and citric acid $(0.025 \mathrm{~g})$ were added to the samples at $70-80^{\circ} \mathrm{C}$ and stirred for $30 \mathrm{~min}$. Then, the oils were filtered at $50^{\circ} \mathrm{C}$.

\section{Analytical methods}

The oil Color was measured by Lovibond PFX995 using $133.35 \mathrm{~mm}$ cell (AOCS method Cc 13b-45, 1997), free fatty acid was calculated according to the AOCS method Ca 5a-40, 1997, and soap content was measured according to the AOCS method Cc 17-95, 1997.

Oxidation was monitored by measuring peroxide value (PV) (AOCS method Cd 8-53, 1997) and p-Anisidine value (p-AV) (ISO method 6885, 2004). In addition, the melting point (MP) (AOCS method Cc 3-25, 1997), iodine value (IV) (AOCS method Cd $1-25,1993$ ), solid fat content (SFC) (AOCS method Cd 16-81, 1997, Brucker minispec, model mq20), and fatty acid composition (AOCS method Ce 1f-96, 1997) were measured.

\section{RESULTS AND DISCUSSIONS}

\subsection{Soybean Oil Hydrogenation}

Bleached soybean oil (SBO); 4.8 red color , 70 yellow color, IV 123.44 , free fatty acid $0.11 \%$ (as Oleic acid), soap content zero ppm, PV zero meq $\mathrm{O}_{2} / \mathrm{kg}$ and $\mathrm{p}-\mathrm{AV} 6$ were used as reference oils.

PV and p-AV increased to $6.56 \mathrm{meq} \mathrm{O}_{2} / \mathrm{kg}$ and 13.5 respectively after the storage time. Six samples were selected during storage at Totox values of $6.2,7.1,7.8,12.6,20$ and 33.7 for subsequent hydrogenation. Reaction times were longer with higher Totox values (Figure 1) as described by Drozdowski et al. (1977).

Resulted SFCs are lower than those obtained with the reference oil as initial Totox is increased (Figure 2). Consequently, less solidification is observed after hydrogenation of oxidized SBO but sometimes this trend is reversed when the Totox value is $\geq 33.7$.

Main fatty acids such as Stearic acid, total trans fats (sum of trans-Oleic, trans-Linoleic and trans-Linolenic acids), Oleic acid, Linoleic acid and Linolenic acid are given in Table 1. Higher Totox values lead the reaction to a non-selective rout as total trans fatty acids are decreased and Linoleic and Linolenic acids are increased. This finding reveals that the oxidized SBO has a poisoning effect on the nickel catalyst. This conclusion can be confirmed by the SFC curve as well.

Resulting IVs of the different hydrogenated samples are shown in Table 2. Defined MPs were achieved at higher IVs; it can be concluded that the oxidation of oil lead to positional isomerization rather than saturation.

So, it can be concluded that SBO with a Totox value $\leq 7$ has normal hydrogenation behavior.

\subsection{Sunflower Oil Hydrogenation}

Bleached sunflower oil (SFO); red color 1, yellow color 14 , IV 125.44 , free fatty acid $0.1 \%$ (as Oleic 
SBO

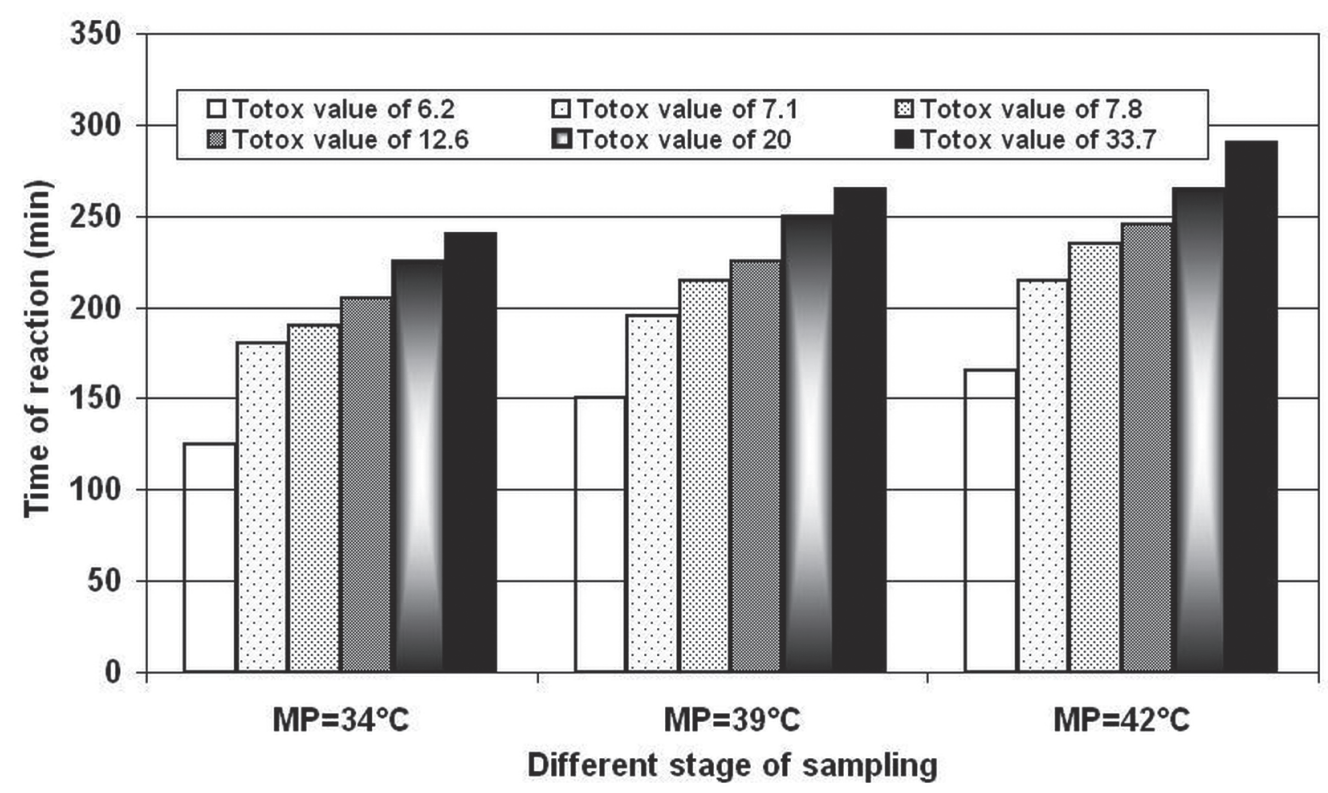

Figure 1.

Hydrogenation of Soybean oil: Reaction times for three stages in samples of different oxidation status.

Table 1

Influence of Totox value on the fatty acid composition of oxidized bleached Soybean oil in different sampling stages of hydrogenation

\begin{tabular}{|c|c|c|c|c|c|c|}
\hline $\begin{array}{l}\text { Sampling } \\
\text { stage }\end{array}$ & Totox value & $\begin{array}{l}\text { Stearic } \\
\text { acid\% }\end{array}$ & Total trans $\%$ & Oleic acid\% & $\begin{array}{l}\text { Linoleic } \\
\text { acid\% }\end{array}$ & $\begin{array}{l}\text { Linolenic } \\
\text { acid } \%\end{array}$ \\
\hline \multirow{6}{*}{ 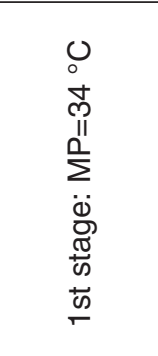 } & 6.2 & 7.86 & 16.90 & 25.51 & 27.76 & 2.28 \\
\hline & 7.1 & 8.25 & 12.85 & 26.11 & 30.41 & 2.71 \\
\hline & 7.8 & 8.33 & 14.17 & 25.79 & 29.74 & 2.87 \\
\hline & 12.6 & 8.16 & 14.20 & 24.14 & 34.97 & 3.60 \\
\hline & 20 & 8.58 & 9.38 & 24.39 & 35.55 & 3.90 \\
\hline & 33.7 & 8.88 & 10.02 & 25.10 & 34.52 & 3.58 \\
\hline \multirow{6}{*}{ 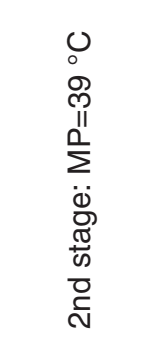 } & 6.2 & 10.99 & 23.18 & 24.42 & 16.24 & 1.14 \\
\hline & 7.1 & 9.61 & 16.64 & 26.62 & 24.72 & 2.06 \\
\hline & 7.8 & 9.82 & 14.09 & 27.89 & 25.53 & 2.20 \\
\hline & 12.6 & 9.43 & 14.20 & 24.08 & 30.25 & 2.89 \\
\hline & 20 & 9.71 & 12.89 & 24.60 & 31.10 & 3.20 \\
\hline & 33.7 & 10.20 & 11.61 & 24.79 & 31.37 & 2.48 \\
\hline \multirow{6}{*}{ 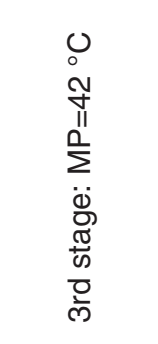 } & 6.2 & 12.76 & 25.82 & 24.06 & 13.05 & 0.80 \\
\hline & 7.1 & 11.66 & 19.01 & 25.55 & 19.48 & 1.42 \\
\hline & 7.8 & 12.37 & 19.98 & 23.99 & 19.62 & 1.58 \\
\hline & 12.6 & 11.56 & 17.51 & 24.15 & 24.23 & 1.62 \\
\hline & 20 & 11.12 & 14.83 & 24.55 & 26.37 & 2.52 \\
\hline & 33.7 & 11.23 & 14.20 & 24.36 & 29.13 & 2.02 \\
\hline
\end{tabular}



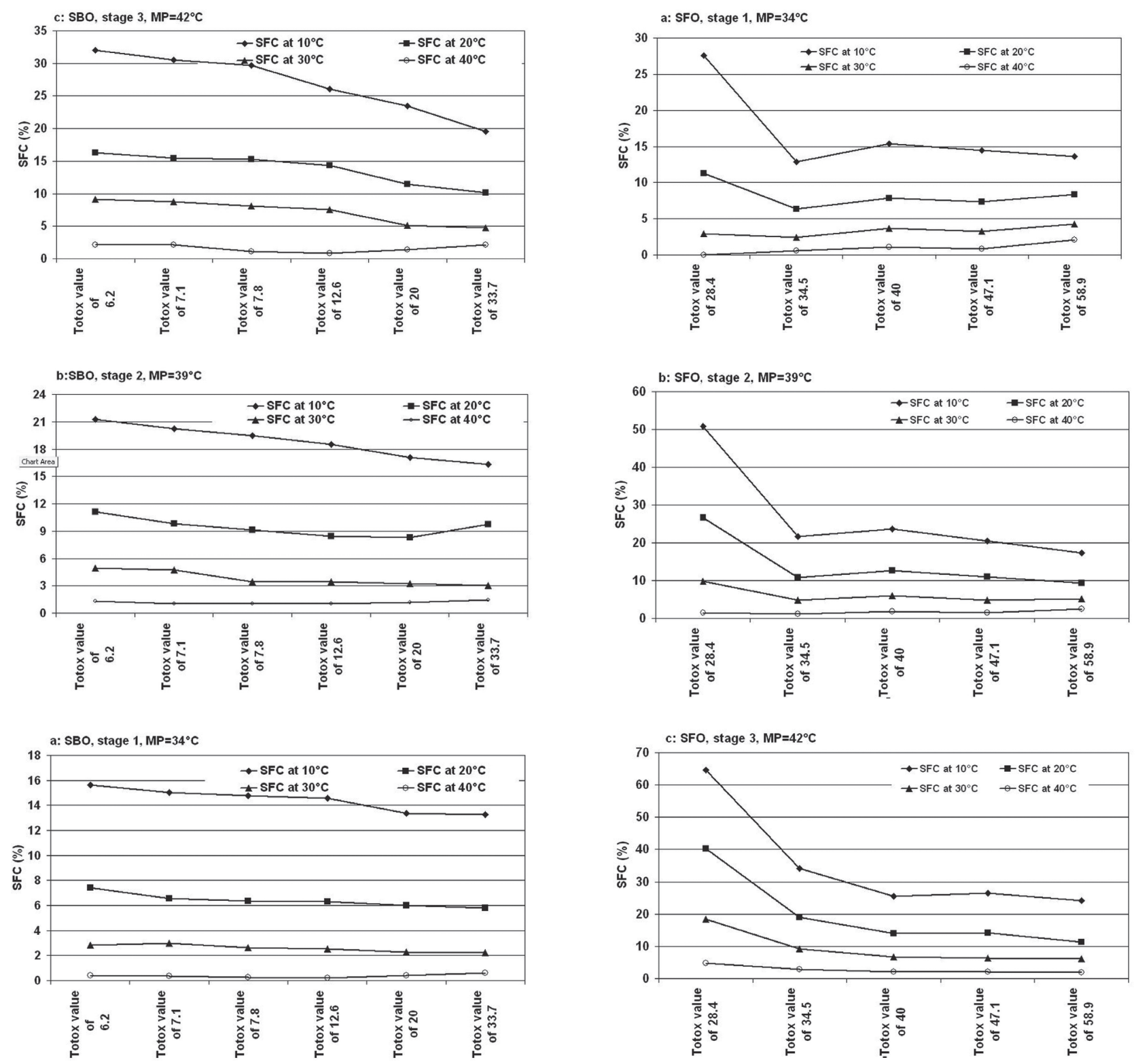

Figure 2.

Hydrogenation of oxidized bleached Soybean oil: solid fat content vs. Totox.

Figure 3.

Hydrogenation of oxidized bleached Sunflower oil: Solid fat content vs. Totox.

acid), soap content zero ppm, PV 4.9meq $\mathrm{O}_{2} / \mathrm{kg}$ and p-AV 18.62 were used as reference sunflower oils.

The reference SFOs were oxidized to different Totox values of $28.4,34.5,40,47.1$, and 58.9; this oxidized oil were hydrogenated. The results show that total reaction times are not changed significantly by Totox $(200 \pm 5 \mathrm{~min})$. The peroxide and $\mathrm{p}$-Anisidine trend in the oxidized oils are shown in Table 3.

SFC changes were depicted against the Totox of oxidized SFO (Figure 3) for which a decreasing trend is observed. This decreasing trend is more visible when the Totox ranged from 28.4 to 34.5 .

The main fatty acids of the hydrogenated oxidized SFOs are given in Table 4. Total trans fats are the sum of trans isomers of Oleic and Linoleic acids. These

data show that hydrogenation will be complicated with oxidation. This complexity is confirmed by SFC results as well. This finding reveals that the autooxidized SFO has a poisoning effect on the nickel catalyst especially at high Totox values.

It can be concluded that auto-oxidation will affect the selectivity of hydrogenation regardless of the hydrogenation setting.

Resulted IVs of the different samples are shown in Table 5. IVs are decreased with Totox value 28.4 but there is not significant change in IV with Totox 58.9. Defined MPs were achieved at higher IVs.

It can be concluded that the hydrogenation reaction is highly affected by auto-oxidation particularly when $\mathrm{PV}$ is more than $5 \mathrm{meq} \mathrm{O}_{2} / \mathrm{kg}$. 
Table 2

lodine value changes in hydrogenated Soybean oil with different Totox values

\begin{tabular}{|c|c|c|c|c|c|c|c|}
\hline \multicolumn{2}{|c|}{ Totox value } & 6.2 & 7.1 & 7.8 & 12.6 & 20 & 33.7 \\
\hline \multicolumn{2}{|c|}{$\mathrm{PV}\left(\right.$ meq $\left.\mathrm{O}_{2} / \mathrm{kg}\right)$} & 0 & 0.6 & 1 & 3.2 & 6.9 & 13.5 \\
\hline \multicolumn{2}{|c|}{$\mathrm{p}-\mathrm{AV}$} & 6.20 & 5.91 & 5.76 & 6.14 & 6.16 & 6.56 \\
\hline \multirow{3}{*}{ 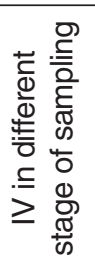 } & $\begin{array}{l}1^{\text {st }} \text { stage: } \\
M P=34^{\circ} \mathrm{C}\end{array}$ & 104.05 & 107.28 & 109.25 & 109.81 & 109.98 & 111.42 \\
\hline & $\begin{array}{l}2^{\text {nd }} \text { stage: } \\
\mathrm{MP}=39^{\circ} \mathrm{C}\end{array}$ & 95.08 & 96.54 & 97.45 & 97.81 & 102.74 & 103.52 \\
\hline & $\begin{array}{l}3^{\text {rd }} \text { stage: } \\
\mathrm{MP}=42^{\circ} \mathrm{C}\end{array}$ & 92.14 & 92.87 & 93.42 & 94.64 & 96.55 & 97.11 \\
\hline
\end{tabular}

Table 3

Oxidation of bleached Sunflower oil during storage (135 days)

\begin{tabular}{|c|c|c|c|c|c|}
\hline PV $\left(\right.$ meq $\left.\mathrm{O}_{2} / \mathrm{kg}\right)$ & 4.90 & 10.90 & 10.50 & 13.76 & 10.00 \\
\hline p-AV & 18.62 & 12.62 & 18.95 & 19.55 & 24.45 \\
\hline Totox value & 28.4 & 34.5 & 40 & 47.1 & 58.9 \\
\hline
\end{tabular}

Table 4

Influence of Totox value on the fatty acid composition of oxidized bleached Sunflower oil in different sampling stages of hydrogenation

\begin{tabular}{|c|c|c|c|c|c|}
\hline Sampling stage & Totox value & Stearic acid \% & Total trans \% & Oleic acid \% & Linoleic acid \% \\
\hline \multirow{5}{*}{ 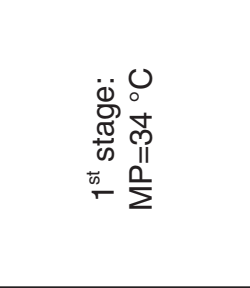 } & 28.4 & 6.20 & 14.50 & 28.79 & 35.85 \\
\hline & 34.5 & 8.52 & 23.44 & 29.63 & 26.72 \\
\hline & 40 & 6.60 & 16.50 & 29.43 & 33.12 \\
\hline & 47.1 & 8.32 & 14.26 & 26.93 & 35.70 \\
\hline & 58.9 & 10.20 & 9.10 & 25.05 & 42.10 \\
\hline \multirow{5}{*}{ 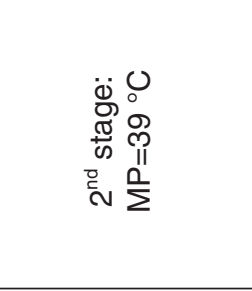 } & 28.4 & 7.17 & 19.90 & 29.80 & 26.59 \\
\hline & 34.5 & 12.81 & 33.56 & 26.64 & 13.53 \\
\hline & 40 & 7.54 & 18.40 & 30.14 & 28.09 \\
\hline & 47.1 & 9.64 & 17.10 & 27.35 & 28.62 \\
\hline & 58.9 & 10.50 & 9.70 & 25.38 & 40.81 \\
\hline \multirow{5}{*}{ 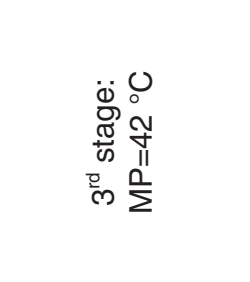 } & 28.4 & 11.12 & 27.14 & 29.92 & 12.20 \\
\hline & 34.5 & 17.23 & 34.87 & 23.66 & 11.25 \\
\hline & 40 & 10.92 & 23.80 & 31.20 & 14.48 \\
\hline & 47.1 & 9.87 & 21.90 & 27.60 & 23.10 \\
\hline & 58.9 & 9.25 & 15.60 & 26.44 & 35.10 \\
\hline
\end{tabular}

\subsection{Canola Oil Hydrogenation}

Bleached canola oil (CNO); red 1.8 , yellow 38, IV 111.26, free fatty acid $0.08 \%$ (as Oleic acid), soap content zero ppm, PV zero meq $\mathrm{O}_{2} / \mathrm{kg}$ and p-AV 4.69 were used as reference .

$\mathrm{PV}$ and $\mathrm{p}-\mathrm{AV}$ increased to $6.3 \mathrm{meq} \mathrm{O}_{2} / \mathrm{kg}$ and 5.74 respectively after storage time. Five samples were selected during the storage time at Totox values 4.7, 5.7, 6.1, 7.5 and 18.3. These samples were hydrogenated. The PV was raised from 1.6 to $6.3 \mathrm{meq} \mathrm{O}_{2} / \mathrm{kg}$ after 90 days. It shows that unsaturation increases the level of oxidation (Steel et al. 2006). Reaction times were longer with higher Totox values (Figure 4).

CNO has similar hydrogenation behavior to what we have observed with SBO and SFO when Totox values are above 5 (Figure 5). But negative 


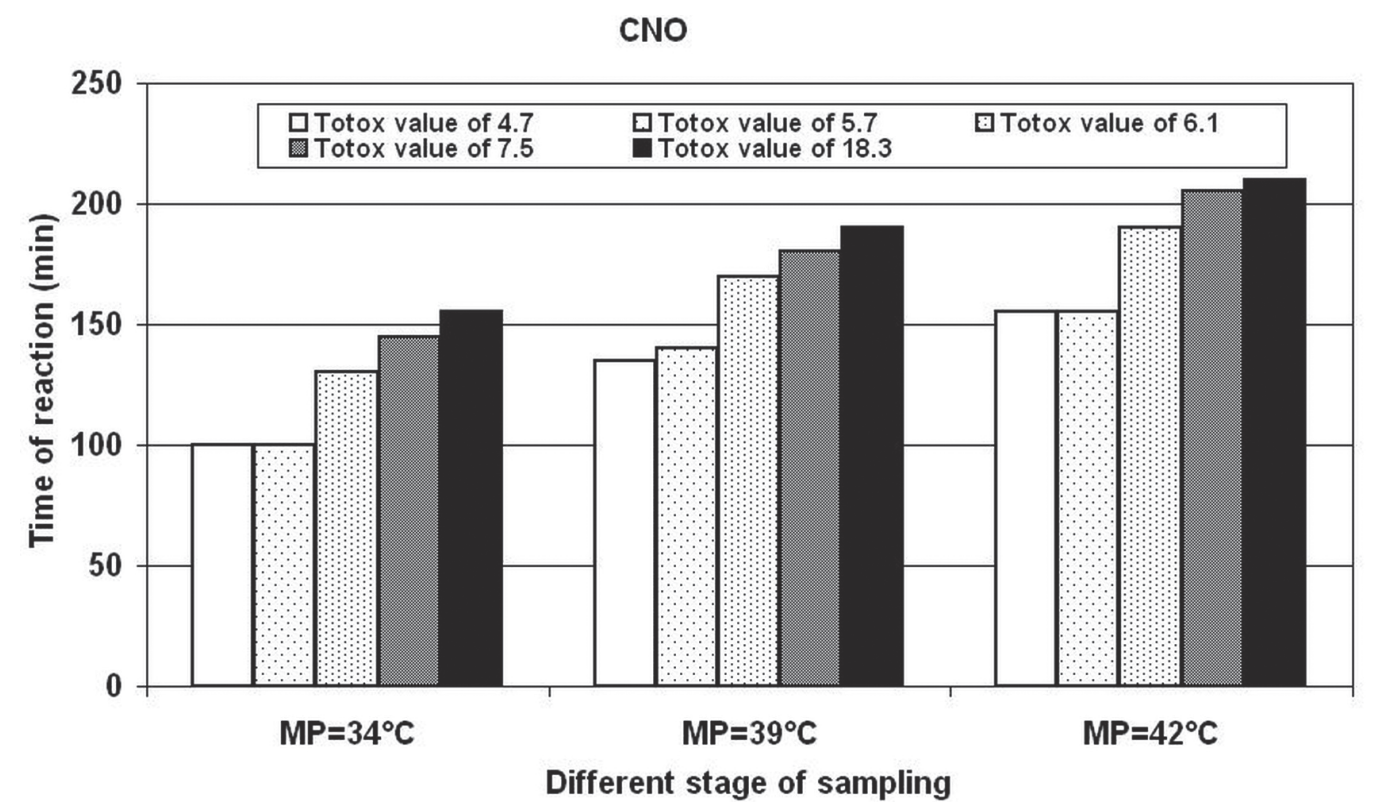

Figure 4.

Hydrogenation of canola oil: Reaction times for three stages in samples of different oxidation status.

Table 5

lodine value changes in hydrogenated Sunflower oil with different Totox values

\begin{tabular}{|c|c|c|c|c|c|c|}
\hline \multicolumn{2}{|c|}{ Totox value } & 28.4 & 34.5 & 40 & 47.1 & 58.9 \\
\hline \multirow{3}{*}{ 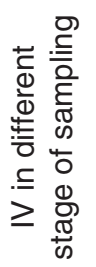 } & $\begin{array}{l}1^{\text {st }} \text { stage: } \\
\mathrm{MP}=34^{\circ} \mathrm{C}\end{array}$ & 84.58 & 106.15 & 103.30 & 105.96 & 110.05 \\
\hline & $\begin{array}{l}2^{\text {nd }} \text { stage: } \\
\mathrm{MP}=39^{\circ} \mathrm{C}\end{array}$ & 73.06 & 94.90 & 94.83 & 96.00 & 107.56 \\
\hline & $\begin{array}{l}3^{\text {rd }} \text { stage: } \\
M P=42^{\circ} \mathrm{C}\end{array}$ & 66.01 & 84.62 & 90.20 & 93.82 & 104.21 \\
\hline
\end{tabular}

Table 6

Influence of Totox value on the fatty acid composition of oxidized bleached Canola oil in different sampling stages of hydrogenation

\begin{tabular}{|c|c|c|c|c|c|c|}
\hline $\begin{array}{l}\text { Sampling } \\
\text { stage }\end{array}$ & $\begin{array}{l}\text { Totox } \\
\text { value }\end{array}$ & $\begin{array}{l}\text { Stearic } \\
\text { acid \% }\end{array}$ & $\begin{array}{c}\text { Total } \\
\text { trans } \%\end{array}$ & $\begin{array}{c}\text { Oleic } \\
\text { acid \% }\end{array}$ & $\begin{array}{c}\text { Linoleic } \\
\text { acid } \%\end{array}$ & $\begin{array}{c}\text { Linolenic } \\
\text { acid } \%\end{array}$ \\
\hline \multirow{5}{*}{ 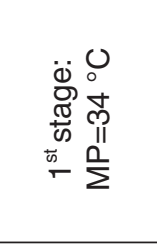 } & 4.7 & 10.58 & 29.37 & 42.85 & 1.29 & 0.24 \\
\hline & 5.7 & 9.75 & 26.22 & 45.90 & 1.79 & 0.11 \\
\hline & 6.1 & 11.09 & 26.54 & 44.51 & 2.00 & 0.77 \\
\hline & 7.5 & 10.53 & 29.37 & 48.90 & 2.58 & 0.32 \\
\hline & 18.3 & 8.43 & 20.45 & 51.95 & 12.36 & 4.20 \\
\hline \multirow{5}{*}{ 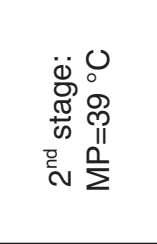 } & 4.7 & 15.27 & 31.84 & 37.89 & 0.70 & 0.19 \\
\hline & 5.7 & 17.97 & 31.06 & 35.99 & 2.13 & 0.19 \\
\hline & 6.1 & 13.92 & 26.55 & 40.38 & 2.99 & 0.10 \\
\hline & 7.5 & 13.17 & 25.95 & 43.42 & 1.52 & 0.11 \\
\hline & 18.3 & 9.18 & 11.45 & 51.30 & 10.97 & 3.64 \\
\hline \multirow{5}{*}{ 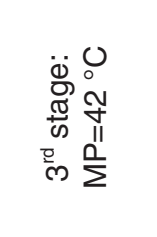 } & 4.7 & 16.74 & 34.42 & 36.28 & 0.27 & 0.10 \\
\hline & 5.7 & 16.99 & 30.94 & 35.37 & 0.60 & 0.19 \\
\hline & 6.1 & 16.71 & 30.73 & 37.46 & 0.72 & 0.15 \\
\hline & 7.5 & 14.49 & 26.63 & 41.48 & 1.57 & 0.14 \\
\hline & 18.3 & 11.74 & 11.85 & 50.00 & 10.04 & 3.23 \\
\hline
\end{tabular}


Table 7

lodine value changes in hydrogenated Canola oil with different Totox values

\begin{tabular}{|c|c|c|c|c|c|c|}
\hline \multicolumn{2}{|c|}{ Totox value } & 4.7 & 5.7 & 6.1 & 7.5 & 18.3 \\
\hline \multicolumn{2}{|c|}{$\mathrm{PV}\left(\right.$ meq $\left.\mathrm{O}_{2} / \mathrm{kg}\right)$} & 0 & 0.6 & 1.1 & 1.6 & 6.3 \\
\hline \multicolumn{2}{|c|}{$\mathrm{p}-\mathrm{AV}$} & 4.69 & 4.54 & 3.91 & 4.34 & 5.74 \\
\hline \multirow{3}{*}{ 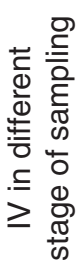 } & $\begin{array}{l}1^{\text {st }} \text { stage: } \\
\mathrm{MP}=34^{\circ} \mathrm{C}\end{array}$ & 75.73 & 79.21 & 78.41 & 89.16 & 96.87 \\
\hline & $\begin{array}{l}2^{\text {nd }} \text { stage: } \\
\mathrm{MP}=39^{\circ} \mathrm{C}\end{array}$ & 70.47 & 70.88 & 74.07 & 78.09 & 93.55 \\
\hline & $\begin{array}{l}3^{\text {rd }} \text { stage: } \\
\mathrm{MP}=42^{\circ} \mathrm{C}\end{array}$ & 68.58 & 67.44 & 71.69 & 75.22 & 92.95 \\
\hline
\end{tabular}
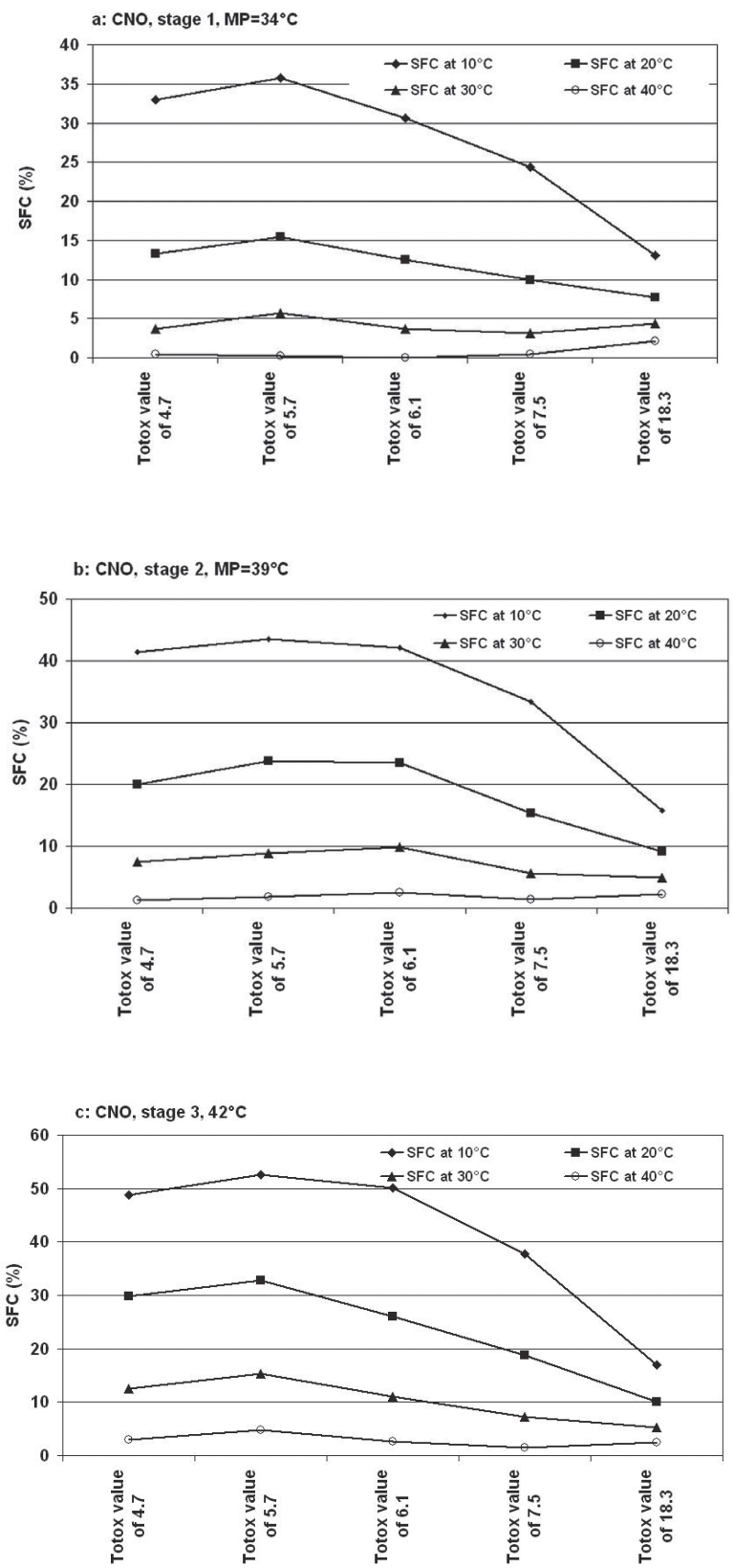

Figure 5 .

Hydrogenation of oxidized bleached Canola oil: solid fat content vs. Totox. slope of the curve occur more frequently than with other oils (about -7) (Fig. 5c).

Main fatty acids such as Stearic acid, total trans fats (sum of trans-Oleic, trans-Linoleic and transLinolenic acids), Oleic acid, Linoleic acid and Linolenic acid are given in Table 6 . The hydrogenation behavior is almost uniform when the Totox ranged from 4.7 to 7.5. This oxidation extent has no significant effect on hydrogenation but it significantly changed the hydrogenation when Totox $\geq 18.3$, as isomerization is dominant in this condition. This finding reveals that the oxidized $\mathrm{CNO}$ has a poisoning effect on the nickel catalyst.

Defined MPs were achieved at higher IVs (Table 7 ). This is similar to what was observed with SBO and SFO.

So, it can be concluded that CNO with a Totox value of $<6$ and $\mathrm{PV}<0.6 \mathrm{meq} \mathrm{O}_{2} / \mathrm{kg}$ has normal hydrogenation behavior.

\section{CONCLUSIONS}

It can be concluded that the hydrogenation process completely depends on oil type, its PV and p-AV. Oil oxidation changes the hydrogenation reaction time and resulting SFCs which are lower when oxidation predominates. It leads the reaction in a non-selective direction. The target MPs are obtained at higher IVs. If we want to control the hydrogenation process to get the predicted results in terms of selectivity under the defined conditions (temperature, pressure, concentration and type of catalyst, agitator rotate) that different researchers used [Koritala 1975; Koritala et al. 1980; EL-Shattory et al. 1980; Kanchan and Shahi et al. 2003; Farooq et al. 2003; Moser et al. 2007; Steel et al. 2006], the Totox value should not be more than 6 , $\mathrm{PV}$ and $\mathrm{p}-\mathrm{AV}$ should be less than $0.5 \mathrm{meq} \mathrm{O} 2 / \mathrm{kg}$ and 5 respectively for any bleached oil. The best results are achievable with a PV and p-AV lower than 5 meq O2/kg and 19 respectively for auto-oxidized oils.

\section{REFERENCES}

AOCS-American Oil Chemists' Society. 1997-1998. Official Methods and Recommended Practices of the American Oil Chemists' Society, $6^{\text {th }}$ ed., AOCS, Champaign. 
Ariaansz RF, Okonek DV. 1998. trans Isomer Control During Edible Oil Processing, In: S.S. Koseoglu, K.C. Rhee (Edits.), Emerging Technologies; Current Practices; Quality Control; Technology Transfer; and Environmental Issues, AOCS Press, Champaign, Illinois, pp. 77-92.

Bockisch M. 1993. Fats and Oils Handbook. AOCS Press, Champaign, Illinois. Ch. 6, P 547.

David BM, Jeffrey MB. 2002. Lipid oxidation of Edible Oil, In: C.A. Casimir, B.M. David (Edits.), Food lipids: chemistry, nutrition, and biotechnology, Marcel Dekker, New York, pp. 335-364.

Debonte LR, Loh WHT, Fun, Z. Canola oil with reduced linolenic acid. Patent no. USPTO 2004/ 6680396.

Dorozdowski B, Zajac M. 1977. Effect of Concentration of some Nickle Catalyst Poisons in Oils on the Course of Hydrogenation. J. Am. Oil Chem. Soc. 54, 595-599.

El-Shattory Y, deMan L, deMan JM. 1980. Evaluation of Hydrogenation Catalyst Activity. J. Am. Oil Chem. Soc. 57, 402-404.

Farooq A, Bhanger MI, Kazi TG. 2003. Relationship between rancimat and active oxygen method values at varying temperatures for several oils and fats. $J$. Am. Oil Chem. Soc. 80, 151-155.

Gustone FD, Harwood JL, Padley FB. 1994. The Lipid Handbook. Chapman \& Hall / CRC.

Hastert RC. 1991. Hydrogenation, In: P.J. Wan (Edit.) Introduction to Fats and Oils Technology, American Oil Chemists' Society, New York, pp. 114-136.

Hastert R. 1987. Proceedings of AOCS Colloquium. American Oil Chemists' Society, Champaign, Illinois.

ISO-International standard organization, 2004. Animal and vegetable fats and oils-Determination of anisidine value.

Kanchan M, Shahi B. 2003. Electrochemical hydrogenation of canola oil using a hydrogen transfer agent. J. Am. Oil Chem. Soc. 80, 1135-1141.

Kellens M. 2000. Oil modification processes, In: W. Hamm, R.J. Hamilton (Edits.), Edible Oil Processing, CRC Press, pp. 129-137.

Koritala S. 1975. Selective Hydrogenation of Soybean Oil: VII Poisons and Inhibitors for Copper Catalyst. J. Am. Oil Chem. Soc. 52, 240-243.

Koritala S, Friendrich JP, Mounts TL. 1980. Selective Hydrogenation of Soybean Oil: Ultra High Pressure and Low Pressure. J. Am. Oil Chem. Soc. 57, 1-5.
Min DB, Hyung-Ok L. 1999. Chemistry of Lipid Oxidation, In: R. Teranish, E.L. Wick, I. Hornstein (Edits.), Flavor chemistry: thirty years of progress, Klumewer Academic/Plenum Publishers, New York, pp. 175-189.

Moser BR, Haas MJ, Winkler JK, Jackson MA, Erhan SZ, List GR, Usda A. 2007. Evaluation of partially hydrogenated methyl esters of soybean oil as biodiesel. Eur. J. Lipid Sci. Technol. 109, 17-24.

Oliver F, Roland MP. 2004. The effect of fatty acid composition on biodiesel oxidative staility. Eur. J. Lipid Sci. Technol. 106, 837-843.

Podmore J. 1990. Controlling Quality in an Edible Oil Refinery, In: D.R. Erickson (Edit.), Edible fats and oil processing, Basic Principle and modern practices: World conference proceeding, American Oil Chemists' Society, Champaign, Illinois, pp. 374-377.

Patterson HBW. 1994. Hydrogenation of Fats and Oils: Theory and Practice. AOCS Press, Champaign, Illinois.

Riegel ER, Kent JA. 2003. Riegel's Handbook of Industrial Chemistry. Kluwer Academic, plenum.

Shahidi F, Zhong Y. 2005. Lipid Oxidation: Measurement Methods, In: F. Shahidi (Edit.), Bailey's Industrial Oil \& Fat Products, Wiley-Interscience, A John Wiley \& Sons, New Jersey, P. 357.

Shahidi F, Wanasundara UN. 2002. Method for Measuring Oxidative Rancidity in Fats and Oils, In: C.C. Akoh, D.B. Min (Edits.), Food Lipids, Marcel Dekker, New York, P. 465.

Steel CJ, Dobarganes MC, Barrera-Arellano D. 2006. Formation of polymerization compounds during thermal oxidation of cottonseed oil, partially hydrogenated cottonseed oil and their blends. Grasas y Aceites 57, 284-291.

Strecker LR, Hasman JM, Maza A. 1986. Quality Characteristics and Properties of the Principal world Oils when processed by physical refining, In: A.R. Baldwin (Edit.), World conference on Emerging Technologies in the fats and Oils Industries, American Oil Chemists' Society, Champaign, Illinois, pp. 51-56.

Wong DWS. 1989. Lipids, In: D.W.S. Wong (Edit.) Mechanism and Theory in Food Chemistry, Academic Press, United state, pp. 1-44. 